\title{
STRATEGI PUBLIKASI ARSIP KEPADA MASYARAKAT MELALUI NASKAH SUMBER ARSIP: STUDI PADA ARSIP UNIVERSITAS GADJAH MADA
}

\author{
Herman Setyawan \\ Kantor Arsip Universitas Gadjah Mada \\ herman.setyawan150482@gmail.com
}

\begin{abstract}
Through the concept of archival study, documents are managed through the stages of records management and archival administration. In the concept of records management, records created through birth and adoption then undergo active life stages of use and maintenance. After the records is useless, the document will enter the stage of death, but there is a reborn/reincarnated archive, the archive that has a continuing value.

Archives that have continuing value are not just stored, you should be utilized for the community. Therefore, the existence of archives should be published to heterogeneous communities through popular publications that are easy to read and easy to understand, one of which is with the source script.
\end{abstract}

Keyword: source script, continuing value

\section{Intisari}

Melalui konsep archival study, dokumen dikelola melalui tahap records management dan archival administration. Dalam konsep records management, arsip yang tercipta melalui pembuatan dan penerimaan kemudian memasuki tahap hidup aktif berupa penggunaan dan pemeliharaan. Setelah arsip tidak berguna maka arsip akan memasuki tahap kematian, namun ada arsip yang terlahir kembali/reinkarnasi, yaitu arsip yang memiliki nilai keberlanjutan.

Arsip yang memiliki nilai keberlanjutan tidak sekedar disimpan, namun harus didayagunakan untuk masyarakat. Oleh karena itu, keberadaan arsip harus dipublikasikan kepada masyarakat yang heterogen melalui publikasi populer yang mudah dibaca dan mudah dipahami, salah satunya adalah dengan naskah sumber.

Kata kunci: naskah sumber, nilai keberlanjutan 


\section{PENDAHULUAN}

Universitas sebagai penyelenggara pendidikan tinggi mengemban tugas utama yaitu penyelenggaraan tri dharma peguruan tinggi yang meliputi pengajaran, penelitian, dan pengabdian kepada masyarakat. Seiring dengan kegiatan-kegiatan tersebut, tentu tercipta informasi yang terekam (recorded information). Salah satu informasi yang terekam disebut sebagai arsip. Arsip memiliki definisi yang bervariatif. Menurut Lundgren dan Lundgren (1989:70), arsip merupakan bukti kejadian atau kegiatan yang direkam dalam bentuk yang nyata sehingga memungkinkan untuk ditemukan kembali. Walne (1988:56) menyatakan bahwa arsip adalah informasi yang terekam dalam bentuk dan media apapun, yang dibuat, diterima, dan dipelihara oleh suatu organisasi, insitusi, atau individu menurut kewajiban hukumnya atau dalam rangka transaksi kegiatan. Sulistyo-Basuki (2005:11) mengatakan bahwa istilah arsip diserap dari Bahasa Belanda archief. Dalam Bahasa Belanda, archief dibedakan menjadi dynamisch archief dan statisch archief. Berkembangnya Bahasa Inggris di Indonesia membawa penyesuaian konteks arsip di Indonesia. Konteks tersebut disebut konteks Anglo-Saxon, yang memaknai dynamisch archief sebagai records (arsip dinamis) dan statisch archief sebagai archives (arsip statis). Sementara itu, Menurut Undangundang nomor 43 tahun 2009, arsip adalah rekaman kegiatan atau peristiwa dalam berbagai bentuk dan media sesuai dengan perkembangan teknologi informasi dan komunikasi yang dibuat dan diterima oleh lembaga negara, pemerintahan daerah, lembaga pendidikan, perusahaan, organisasi politik, organisasi kemasyarakatan, dan perseorangan dalam pelaksanaan kehidupan bermasyarakat, berbangsa, dan bernegara.

Dalam kajian kearsipan, dikenal konsep records management dan archival administration. Records Management menurut Pearce-Moses (2005:334) adalah pengendalian arsip secara sistematis dan administratif sepanjang siklus hidup mereka untuk memastikan efisiensi dan penghematan dalam penciptaan, penggunaan, penanganan, pengendalian, pemeliharaan, dan disposisi. Sementara itu, Griffin (2009:34) menyatakan bahwa records management adalah bidang manajemen yang bertanggung jawab mengontrol secara efisien dan sistematis dalam pembuatan, penerimaan, pemeliharaan, penggunaan dan penyusutan arsip. Dalam kajian kearsipan di Indonesia, konsep records management dikenal dalam undangundang kearsipan dengan istilah pengelolaan arsip dinamis, yaitu proses pengendalian arsip dinamis secara efisien, efektif, dan sistematis meliputi penciptaan, penggunaan dan pemeliharaan, serta penyusutan arsip. Menurut Undang-undang nomor 43 tahun 2009 tentang kearsipan, arsip dinamis adalah arsip yang digunakan secara langsung dalam kegiatan pencipta arsip dan disimpan selama jangka waktu tertentu. Arsip dinamis dibedakan menjadi tiga, yaitu: (1) arsip vital, (2) arsip aktif, dan (3) arsip inaktif.

Konsep-konsep tersebut tidaklah jauh berbeda dengan konsep life cycle of records yang dicetuskan oleh Theodore Roosevelt Schellenberg dari Arsip Nasional Amerika Serikat pada 1934. Model ini membagi daur hidup arsip: (1) Penciptaan atau penerimaan (tahap lahir arsip); (2) Penggunaan dan pemeliharaan arsip dinamis (tahap hidup produktif); dan (3) Tahap penyusutan arsip dinamis (tahap kematian) atau pemindahan ke tempat arsip statis/reinkarnasi (Ricks \& Gow, 
1988:4). Pada intinya adalah arsip tercipta seiring dengan kegiatan administrasi, dan setelah masa penggunaannya selesai, maka arsip tersebut seharusnya disusutkan. Namun terdapat sebagian arsip yang tidak boleh dimusnahkan.

Kennedy dan Schauder (1998:9) meyatakan bahwa akhir dari daur hidup arsip dinamis akan memasuki tahap/ siklus hidup ke dua sebagai arsip yang diidentifikasikan dan dinilai sebagai arsip yang memiliki continuing value, dikumpulkan, dicatat informasinya, dipelihara, serta diberikan atau disediakan akses arsipnya. Pearce-Moses (2005:91) menyatakan bahwa continuing value adalah kegunaan atau signiPikasi jangka panjang suatu arsip yang didasarkan pada nilai guna administrasi, hukum, fiskal, kebuktian, atau historis yang terkandung di dalamnya dan perlu dilestarikan terus-menerus. Dalam bahasa undang-undang kearsipan, arsip semacam ini dikenal dengan istilah arsip statis, yaitu arsip yang dihasilkan oleh pencipta arsip karena memiliki nilai guna kesejarahan, telah habis retensinya, dan berketerangan dipermanenkan yang telah diverifikasi baik secara langsung maupun tidak langsung oleh Arsip Nasional Republik Indonesia dan/atau lembaga kearsipan.

Arsip statis dikelola dengan konsep archival administration. Menurut PearceMoses (2005:33), archival administration/archives management adalah pengawasan umum program untuk menilai, memperoleh, mengatur dan mendeskripsikan, melestarikan, mengotentikasi, dan menyediakan akses arsip yang bernilai permanen. Dalam bahasa undang-undang kearsipan, konsep ini dikenal dengan istilah pengelolaan arsip statis, yaitu proses pengendalian arsip statis secara efisien, efektif, dan sistematis meliputi akuisisi, pengolahan, preservasi, pemanfaatan, pendayagunaan, dan pelayanan publik dalam suatu sistem kearsipan nasional.
Suatu hal yang menjadi kesenjangan dalam pengelolaan arsip statis adalah bahwa arsip statis telah habis retensinya, sehingga muncul enigma: untuk apa arsip statis itu disimpan secara permanen? Apabila jawabannya adalah karena arsip statis memiliki nilai keberlanjutan, lalu apakah arsip statis cukup disimpan hingga akhir zaman? Jika demikian, arsip statis bagaikan menjadi harta kekayaan yang meskipun bernilai tinggi tetapi tidak mendatangkan manfaat bagi pemiliknya, apalagi bagi masyarakat. Lalu munculah sebuah tantangan, bagaimana startegi mempublikasikan khazanah arsip statis agar dapat dimanfaatkan keberadaannya sebagai sumber informasi bagi masyarakat?

\section{Metodologi Penelitian}

1. Objek Penelitian

Objek penelitian ini adalah arsip universitas/arsip perguruan tinggi yang didirikan tahun 2004 sebelum terbitnya UU No. 43 Tahun 2009. Pada tahun 2009 melalui UU No. 43 Tahun 2009 tentang Kearsipan menyebutkan bahwa seluruh perguruan tinggi negeri diwajibkan membentuk arsip perguruan tinggi. Kajian ini mengambil sampel Arsip UGM yang memiliki kebutuhan strategi berbeda dengan arsip perguruan tinggi lainnya.

2. Metode Penelitian

Penelitian ini menggunakan metode studi kasus, riset yang menggunakan contoh salah satu kasus sebagai model pengembangan riset selanjutnya. Berbagai sumber data didapatkan untuk dapar mengumpulkan data, menguraikan, dan menjelaskan secara menyeluruh berbagai aspek untuk mengembangkan publikasi Arsip UGM.

3. Teknik Pengumpulan Data

Teknik pengumpulan data yang akan digunakan dalam penelitian ini meliputi :

a. Observasi partisipasi

Pengumpulan data melalui proses 
pengamatan dan mencatat secata sistematis gejala-gejala yang diselidiki atau diteliti. Peneliti terlibat dengan kegiatan seharihari dengan sumber penelitian yaitu Arsip UGM karena peneliti merupakan pegawai di Arsip UGM. Proses observasi partisipasi ini bertujuan untuk meperoleh data yang lengkap, tajam, hingga mengetahui pada tingkat dari setiap perilaku yang nampak.

b. Studi pustaka

Selain mengumpulkan buku, dokumen dan arsip yang berkaitan dengan aktivitas UGM di Arsip UGM.

4. Teknik Analisis Data

Teknik analisa data dalam penelitian ini dimulai dengan menganalisis berbagai data yang berhasil dikumpulkan melalui wawancara, observasi partisipasi dan studi pustaka. Data-data tersebut kemudian diverifikasi dan diinterpretasikan sesuai dengan kebutuhan data penelitian. Setelah verifikasi dan interpretasi, dilakukan analisa terhadap data tersebut agar dapat menjawab pertanyaan dalam penelitian ini.

\section{HASIL DAN PEMBAHASAN}

Arsip Universitas Gadjah Mada adalah lembaga kearsipan perguruan tinggi/university archives di Universitas Gadjah Mada (UGM). Maher (1992;17) meyatakan bahwa university archives adalah suatu program terpadu yang terdiri dari kebijakan, sumber daya manusia, dan sumber daya lainnya berupa khazanah yang dimilikinya, serta fasilitas yang tersedia untuk merawat dan melestarikan serta menyediakan akses warisan dokumenter suatu perguruan tinggi.

Dalam konsep records management, Arsip Universitas harus memainkan peran kunci dalam pengembangan dan implementasi program manajemen arsip dinamis di lingkungan universitas (The Society of American Archivists:1979). Kebijakan mengenai program pengelolaan arsip harus memperhatikan: (1) Peningkatan kualitas rekaman dengan mengevaluasi dan mengendalikan dalam penciptaan arsip, bentuk, dan sistem pengarsipan; (2) Peningkatan penggunaan kertas yang saat ini digunakan dalam organisasi; (3) Peningkatan dalam pengendalian dan akses terhadap informasi yang dibutuhkan; (4) Kepatuhan terhadap undang-undang yang mengatur kearsipan; (5) Identifikasi dan perlindungan terhadap arsip yang penting bagi kelanjutan institusi; (6) Pelestarian arsip yang penting atau memiliki nilai permanen; dan (7) Penghapusan arsip inaktif yang tidak diperlukan untuk kelangsungan operasi organisasi. Sementara itu, misi inti Arsip Universitas adalah: untuk menilai, mengumpulkan, mengatur, menggambarkan, menyediakan, dan pemrograman arsip bernilai historis, fiskal, dan /atau administratif bagi institusinya; menyediakan fasilitas yang memadai untuk menyimpan dan melestarikan arsip tersebut; memberikan layanan informasi yang akan membantu pengoperasian institusi; menjadi sumber dan laboratorium untuk menstimulasi dan mendorong pengajaran dan pembelajaran yang kreatif; untuk melayani penelitian dan beasiswa dengan menyediakan dan mendorong penggunaan koleksinya oleh anggota institusi dan masyarakat luas; untuk mempromosikan pengetahuan dan pemahaman tentang asal usul, tujuan, program, dan tujuan institusi, dan pengembangan tujuan, sasaran, dan program institusi; dan ntuk memudahkan pengelolaan arsip yang efisien.

Dengan visi "Menjadi pusat pengembangan dan layanan informasi kearsipan dalam menunjang universitas riset kelas dunia dan bertata kelola baik", 
Arsip UGM mempunyai misi: (1) Menyelamatkan arsip universitas sebagai sumber informasi dan memori kolektif Universitas Gadjah Mada; (2) Melaksanakan pengelolaan arsip statis (Archives Management), pengelolaan arsip inaktif dan pengembangan Records Center, serta pengembangan teknologi informasi kearsipan; dan (3) Melaksanakan dan mengoptimalkan layanan internal dan eksternal informasi kearsipan. Sesuai dengan Pearturan Rektor UGM nomor 1/P/SK/HT/2015 tentang Kedudukan, Fungsi, dan Tugas Organisasi di Lingkungan Universitas Gadjah Mada, Arsip UGM berfungsi sebagai pengelola dan penyelenggara layanan kearsipan di lingkungan UGM. Arsip UGM bertugas: (1) menyusun startegi kebijakan Arsip UGM; menyusun petunjuk pelaksanaan penyelenggaraan arsip; mengoordinasi pengelolaan dan pelestarian arsip; (4) mengoordinasi layanan di bidang kearsipan; (5) mengoordinasi pengembangan sistem kearsipan; (6) mengoordinasi dan mengevaluasi penyelenggaraan arsip di lingkungan UGM; (7) melakukan pembinaan terhadap sumber daya manusia arsip UGM; dan (8) melakukan pembinaan terhadap penyelenggaraan kearsipan di lingkungan UGM. Tugastugas tersebut berhubungan dengan pengelolaan arsip statis yang meliputi akuisisi, pengolahan, preservasi, dan akses. Dalam undang-undang kearsipan disebutkan bahwa akuisisi arsip statis adalah proses penambahan khasanah arsip statis pada lembaga kearsipan yang dilaksanakan melalui kegiatan penyerahan arsip statis dan hak pengelolaannya dari pencipta arsip kepada lembaga kearsipan. Selama berdirinya, Arsip UGM telah mengakuisisi ribuan berkas dalam berbagai bentuk dan media. Sebagian besar arsip hasil akuisisi telah diolah, baik berupa arsip tekstual (57797 berkas), arsip rekaman suara (1495 berkas), arsip video (2000 berkas), arsip foto (22486 berkas foto positif dan 5925 berkas foto negatif), arsip film (244 berkas), dan arsip kartografi (482 berkas). Akuisisi dilakukan terhadap unit -unit kerja di lingkungan UGM maupun perseorangan.

Setelah tahap akuisisi, arsip statis kemudian diolah, yaitu pengolahan arsip berdasarkan standar deskripsi arsip statis dan dilaksanakan berdasarkan asas asal usul dan asas aturan asli. Pengolahan arsip statis meliputi kegiatan penataan informasi arsip statis, fisik arsip statis, dan penyusunan sarana bantu temu balik arsip statis. Deskripsi arsip statis setidaknya memuat asal arsip, jumlah, nomor berkas, kode klasifikasi arsip statis, uraian, kurun waktu, dan lokasi simpan arsip.

Untuk menjamin keselamatan dan kelestariannya, arsip statis yang telah diolah perlu dilakukan preservasi baik secara preventif (mencagah kerusakan) maupun kuratif (memperbaiki kerusakan). Preservasi preventif dilakukan dengan penyimpanan (pengaturan suhu dan kelembaban ruang simpan arsip, penaturan cahaya, dan lainlain), pengedalian hama secara terpadu, reproduksi (alih media arsip ke dalam format lain, termasuk format digital), dan perencanaan menghadapi bencana. Sementara itu, preservasi kuratif dilakukan dengan proses deasidifikasi, laminasi, dan enkapsulasi.

Tahap akhir peengelolaan arsip statis adalah akses, yaitu ketersediaan arsip sebagai hasil dari kewenangan hukum dan otorisasi legal serta keberadaan sarana bantu untuk mempermudah penemuan dan pemanfaatan arsip. Menurut PearceMoses (2005:2), akses adalah kemampuan untuk menemukan informasi yang relevan melalui penggunaan katalog, indeks, alat temu kembali, atau alat lainnya; izin untuk mencari dan mengambil informasi untuk digunakan sebagai bahan konsultasi atau 
referensi dari adanya larangan yang ditetapkan secara hukum mengenai privasi, kerahasiaan, dan keamanan; dan pengambilan informasi dari media penyimpanan. Sementara itu menurut Griffin (2009:5), akses adalah hak, kesempatan atau cara menemukan, menggunakan atau mengambil informasi.

Peraturan Pemerintah nomor 28 tahun 2012 menyebutkan bahwa akses arsip statis dilaksanakan dalam rangka pemanfaatan, pendayagunaan, dan pelayanan publik. Akses arsip statis untuk kepentingan pengguna arsip dijamin oleh lembaga kearsipan. Akses arsip statis dilaksanakan dengan mempertimbangkan: (1) prinsip keutuhan, keamanan, dan keselamatan arsip statis; dan (2) sifat keterbukaan dan ketertutupan arsip sesuai dengan ketentuan peraturan perundangundangan.

Untuk menjamin kepentingan akses, lembaga kearsipan menyediakan prasarana dan sarana akses arsip statis. Arsip UGM wajib menyediakan arsip sebagai sumber informasi bagi masyarakat, termasuk bagi sivitas akademika. Sivitas akademika di UGM memiliki latar belakang yang beragam, seperti dosen, peneliti, mahasiswa, dan tenaga kependidikan. Tidak sedikit dari mereka menggunakan arsip dalam berbagai keperluan. Sementara itu, UGM telah lahir sejak tahun 1949, sehingga dipastikan arsip statis yang dikelola oleh Arsip UGM tentulah sangat banyak jumlah dan perihalnya. Dua hal tersebut menuntut Arsip UGM untuk dapat menyediakan informasi khazanah arsip yang dimilikinya kepada khalayak. Salah satu cara yang dapat dilakukan oleh Arsip UGM adalah dengan menerbitkan naskah sumber arsip.

Naskah sumber arsip merupakan sebuah buku/cetakan yang berisi khazanah arsip yang memuat sekelompok tema tertentu, yang disusun dengan tujuan untuk menunjukkan atau mempublikasikan khazanah arsip statis kepada masyarakat. Kelompok tema dapat diambil secara umum maupun spesifik. Tema umum artinya adalah sekelompok tema yang umum terjadi atau terdapat pada berbagai institusi, sedangkan tema spesifik hanya dimiliki oleh institusi tertentu. Contoh kelompok tema umum di lembaga perguruan tinggi antara lain: kuliah kerja nyata (KKN), penerimaan mahasiswa baru, prestasiprestasi sivitas akademika, infrstruktur, wisuda, dies natalis, peristiwa-peristiwa bersejarah universitas, dan sebagainya. Sedangkan contoh tema spesifik di UGM adalah ketokohan Prof. Sardjito, penganugerahan gelar Hamengkubuwono IX Awards, Wanagama, dan sebagainya.

Penyusunan naskah sumber merupakan tugas arsiparis. Arsiparis adalah seseorang yang memiliki kompetensi di bidang kearsipan yang diperoleh melalui pendidikan formal dan/atau pendidikan dan pelatihan kearsipan serta mempunyai fungsi, tugas, dan tanggung jawab melaksanakan kegiatan kearsipan. Oleh karena penyusunan naskah sumber tidak sekedar pekerjaan teknis, dalam melaksanakan tugasnya, arsiparis dituntut untuk memiliki kemampuan intelektual yang sama bagusnya dengan kemampuan teknikal. Kemampuankemampuan intelektual dalam penyusunan naskah sumber antara lain: (1) Melakukan identifikasi dan penilaian, (2) Melakukan penelusuran referensi sesuai tema, (3) Melakukan penulisan draf, dan (4) Melakukan editing draf. Sementara itu kemampuan teknikal terlihat pada kegiatan pemindaian dan menilai hasil pindaian serta menyusun tata letak naskah sumber.

Saat ini Arsip UGM tekah menyusun enam seri naskah sumber arsip. Dengan disusunnya naskah sumber tersebut diharapkan dapat merangsang user untuk memanfaatkan khazanah arsip statis yang dikelola oleh Arsip UGM. Berikut naskah sumber yang pernah diterbitkan oleh 
Arsip UGM:

1. UGM di Forum Internasional

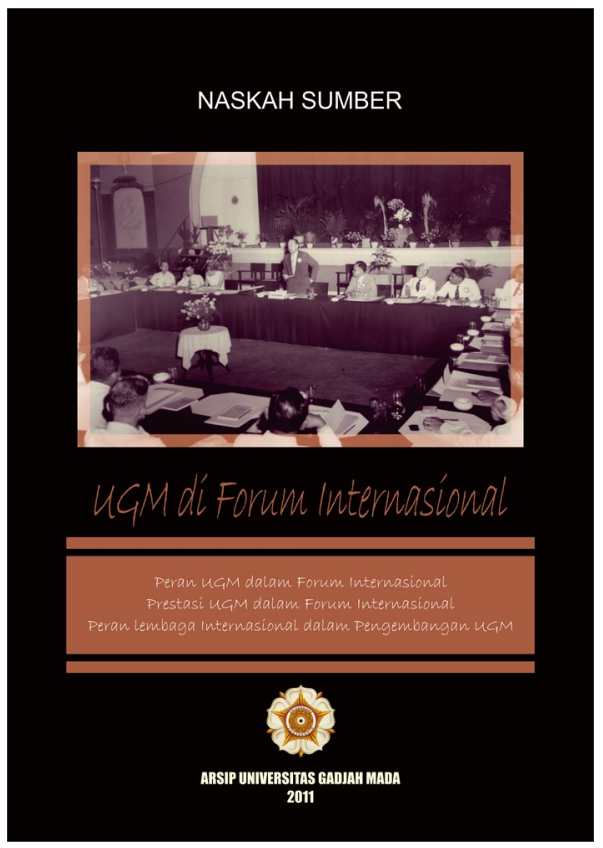

Naskah sumber seri pertama yang berjudul "UGM di Forum Internasional" ini bercerita bahwa sejak didirikan pada tahun 1949, sivitas akademika UGM telah banyak terlibat dalam forum internasional. Naskah sumber ini disusun dari kumpulan khazanah berupa foto dan arsip tekstual. Naskah sumber ini disusun tahun 2011. Naskah sumber ini dibagi ke dalam tiga sub judul, yaitu:

a. Peran UGM dalam Forum Internasional

b. Prestasi UGM dalam Forum Internasional

c. Peran lembaga Internasional dalam Pengembangan UGM

2. Prosesi Penerimaan Mahasiswa Baru Universitas Gadjah Mada 1950 $-2001$

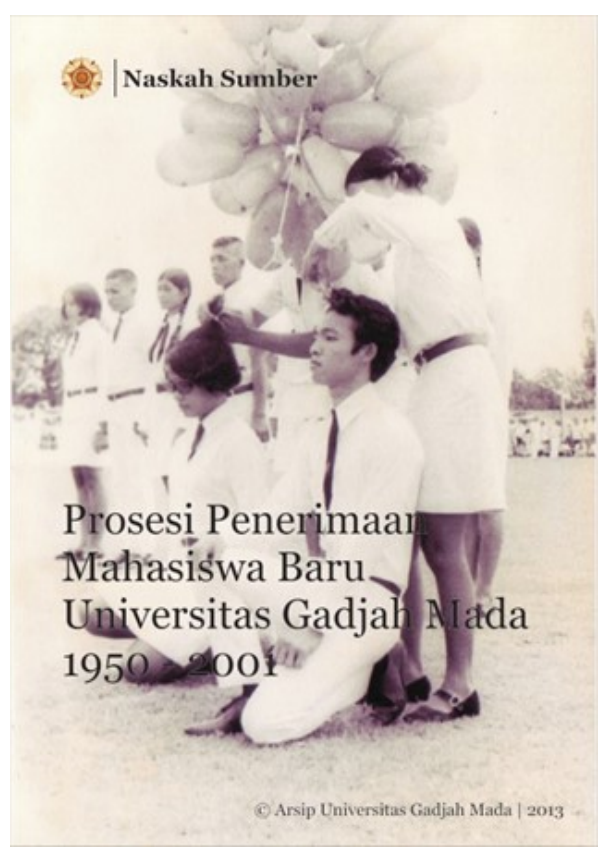

Naskah Sumber Seri 2 yang berjudul "Prosesi Penerimaan Mahasiswa Baru Universitas Gadjah Mada 1950-2012" ini berisi tentang ragam penerimaan mahasiswa baru sejak UGM berdiri hngga tahun 2012. Selain sebagai memori, naskah sumber ini mengajak kepada user untuk menemukan nilainilai historis dari berbagai penyelenggaraan penerimaan mahasiswa baru yang sangat beragam. Naskah sumber ini dibagi ke dalam 11 periode berdasarkan masa kerektoran, yaitu:

a. Masa kerektoran Prof. Dr. M. Sardjito (1949-1961)

b. Masa kerektoran Prof. Dr. Ir. Herman Johannes (1961-1966)

c. Masa kerektoran drg. M. Nazir Alwi (1966-1967)

d. Masa kerektoran Prof. Soepojo Padmodiputro, M.A.

e. Masa kerektoran Prof. Dr. Soeroso H. Prawirohardjo

f. Masa kerektoran Prof. Dr. Soekdaji Ranuwihardjo, M.A.

g. Masa kerektoran Prof. Dr. Teuku Jacob

h. Masa kerektoran Prof. Dr. Koesnadi Hardjasoemantri 
i. Masa kerektoran Prof. Dr. Mochammad Adnan, M.Sc.

j. Masa kerektoran Prof. Dr. Soekanto Reksohadiprodjo, M.Com., dan

k. Masa kerektoran Prof. Dr. Ichlasul Amal, M.A.

3. Pemilihan Rektor UGM dari Masa ke Masa 1950 - 2012

Naskah sumber seri 3 berjudul "Pemilihan Rektor UGM dari Masa ke Masa 1950-2012" yang diterbitkan pada tahun 2013 merupakan upaya Arsip UGM untuk menyebarluaskan khazanah arsip yang dimiliki Arsip UGM kepada publik serta nilai-nilai historis perjalanan pemilihan rektor UGM sejak UGM didirikan sampai tahun 2012. Selama itu, UGM telah melaksanakan pemilihan rektor sebanyak 14 kali. Berbagai hal berbau demokrasi terlihat jelas melalui naskah sumber ini. Transformasi nilai-nilai historis dan demokrasi itu tidak hanya dimaksudkan untuk mengenang jasa individu tetapi juga nilai-nilai kejuangan dari semua pihak yang terlibat dan telah menyumbangkan dharma baktinya untuk kemajuan UGM.

Naskah sumber ini dibagi ke dalam tiga periode. Periode pertama (1950 -1980) berisi tentang personal file Prof. Dr. M. Sardjito, Prof. Dr. Ir. Herman Johannes, Prof. Drg. M Nazir Alwi, Prof. Soepojo Padmodiputro, M.A., Prof. Dr. Soeroso H. Prawirohardjo, dan Prof. Dr. Soekdaji Ranuwihardjo, M.A. Sementara itu, periode ke dua (1980-2000) berisi tentang personal file Prof. Dr. Teuku Jacob, Prof. Dr. Koesnadi Hardjasoemantri, Prof. Dr. Mochammad Adnan, M.Sc., Prof. Dr. Soekanto Reksohadiprodjo, M.Com., dan Prof. Dr. Ichlasul Amal, M.A. Sedangkan periode ke tiga (2000-2012) berisi personal file
Prof. Dr. Sofian Effendi, MPIA., Prof. Ir. Sudjarwadi, M.Eng., Ph.D., dan Prof. Dr. Pratikno. Selain personal file, setiap periode juga menyuguhkan berbagai dokumen terkait pemilihan rektor di UGM.

4. Kuliah Kerja Nyata UGM $1973-2008$

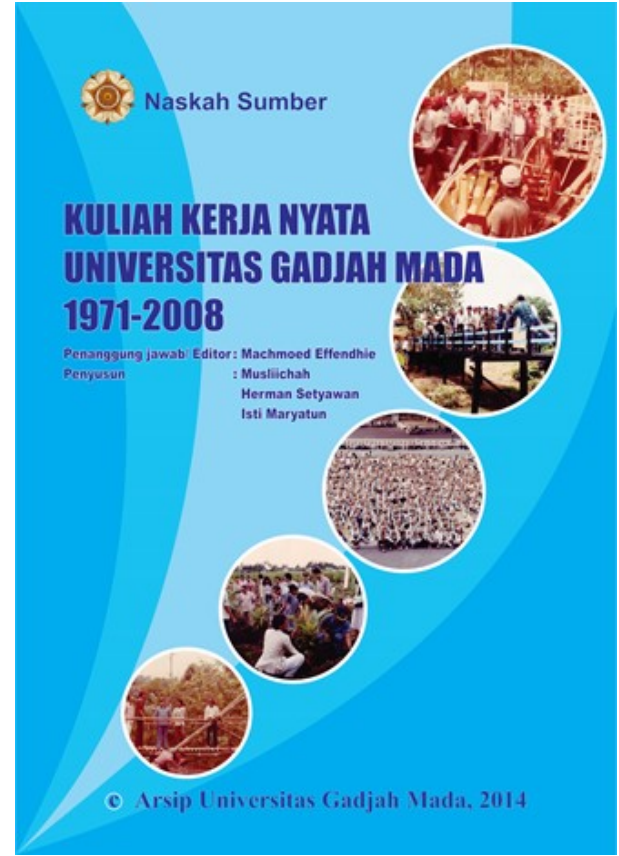

Naskah Sumber Seri 4 ini tentang "Kuliah Kerja Nyata Universitas Gadjah Mada 1971-2008", merupakan salah satu upaya untuk menyebarluaskan khazanah arsip yang dimiliki Arsip UGM kepada publik. Selain itu, nilai-nilai historis perjalanan pengabdian insan akademika UGM kepada masyarakat, terutama di pedesaan, juga perlu didesiminasikan kepada publik. Transformasi nilai-nilai historis itu tidak hanya dimaksudkan untuk mengenang jasa individu, insan akademika UGM, tetapi juga nilai-nilai kejuangan dari semua pihak yang terlibat dan telah menyumbangkan dharma baktinya untuk kemajuan UGM dan bangsa.

Naskah sumber ini diawali dengan kisah Pengerahan Tenaga 
Mahasiswa (PTM), Program Bimbingan Massal (Bimas) di Institut Teknologi Bogor (IPB), dan Tenaga Kerja Sukarela (TKS) yang dikoordinir oleh Badan Urusan Tenaga Sukarela Indonesia (BUTSI) yang memberikan bahan-bahan dan informasi bagi Departemen $\mathrm{P}$ dan K/ Direktorat Pendidikan Tinggi untuk mengembangkan kegiatan pengabdian masyarakat oleh mahasiswa secara menyeluruh untuk semua universitas/ institut negeri yang disebut Kuliah Kerja Nyata (KKN). Tahun 1976 Dirjend Dikti mengeluarkan Pedoman Pelaksanaan KKN. Dalam pedoman tersebut dijelaskan bahwa pada tahun 1973 KKN telah dilaksanakan oleh 10 universitas negeri kemudian tahun 1976 seluruh PTN telah melaksanakan KKN.

PTM menjadi salah satu embrio KKN. Salah satu tokoh dan pelaku PTM adalah Koesnadi Hardjasoemantri, mahasiswa UGM yang kemudian juga pernah menjabat sebagai Rektor UGM (1986-1990). Pengalamannya sebagai pelaku PTM menjadi bekal untuk merumuskan KKN. Prof. Dr. Koesnadi Hardjasoemantri, S.H., ML. mendapatkan Anugerah Perintis Kuliah Kerja Nyata dari pemerintah atas jasanya sebagai pencetus program pengabdian mahasiswa lewat KKN sehingga Beliau dijuluki sebagai Bapak Kuliah Kerja Nyata.

Peraturan yang mengatur tentang penyelenggaraan KKN di UGM yaitu SK Rektor No. 28 Tahuun 1976 menjelaskan bahwa KKN dapat memberikan manfaat kepada : (1) Masyarakat dan Negara, YAITU mendapat bantuan tenaga mahasiswa sebagai penunjang dalam rangka akselerasi pembangunan; (2) Perguruan Tinggi/UGM, yaitu mendapat umpan balik berupa masalah dan bahan pemikiran guna meningkatkan kualitas dalam pelaksanaan Tri Dharma Perguruan Tinggi; dan (3) Mahasiswa, yaitu mendapat pengalaman langsung berpartisipasi dalam pembangunan yang dapt mendewasakan diri dalam segala hal.

Sejarah perkembangan KKN dalam Pedoman KKN Tematik Kontekstual UGM tahun 2006 menjelaskan bahwa KKN melalui berbagai fase/ periode perkembangan yaitu :
a. periode Perintisan (1971-1976)
b. Periode Peralihan (1977-1979)
c. Periode Pemantapan (1979- 1990)
d. Periode Pengembangan (1990- 1997)
e. Periode Transformasi (1998- 2005)
f. Periode KKN Tematik Kontekstual (sejak 2006)

5. Perjalanan kelembagaan Universitas Gadjah Mada 19461977

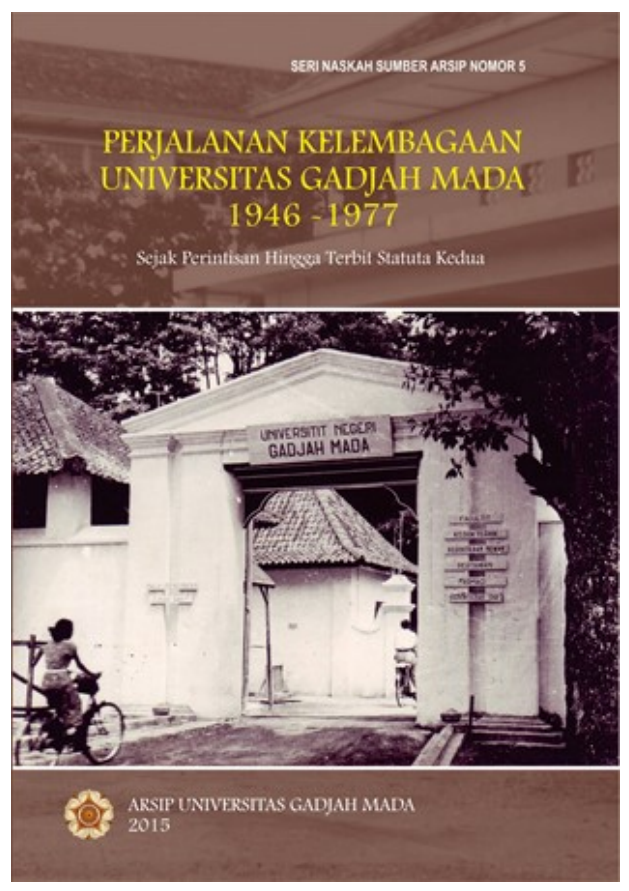


Naskah sumber ini menyajikan hasil penelusuran tentang perkembangan kelembagaan UGM sejak tahun 1946 hingga tahun 1977. Pengambilan periode tahun ini didasarkan pada suatu pertimbangan bahwa tahun 1946 merupakan tahun pendirian Badan Perguruan Tinggi Gadjah Mada (BPT Gadjah Mada) yang merupakan salah satu embrio/cikal bakal UGM. Tahun 1977 merupakan tahun terbitnya statuta kedua UGM yang menggantikan statuta pertama UGM yang terbit tahun 1950. Dengan demikian naskah sumber ini berupaya menyajikan gambaran kelembagaan UGM dalam satu periode yang dimulai sejak embrio UGM hingga terbitnya statuta kedua UGM tahun 1977.

Dalam penyusunannya, naskah sumber ini terbagi atas lima bab, yaitu:
a. Bab I. Rintisan pendirian UGM
b. Bab II. Perkembangan kelembagaan UGM periode tahun 1950-1957
c. Bab III. Perkembangan kelembagaan UGM periode tahun 1958-1965
d. Bab IV. Perkembangan kelembagaan UGM periode tahun 1966-1973
e. Bab V. Perkembangan kelembagaan UGM periode tahun 1974-1977

6. Dies Natalis UGM Periode 1950-1995

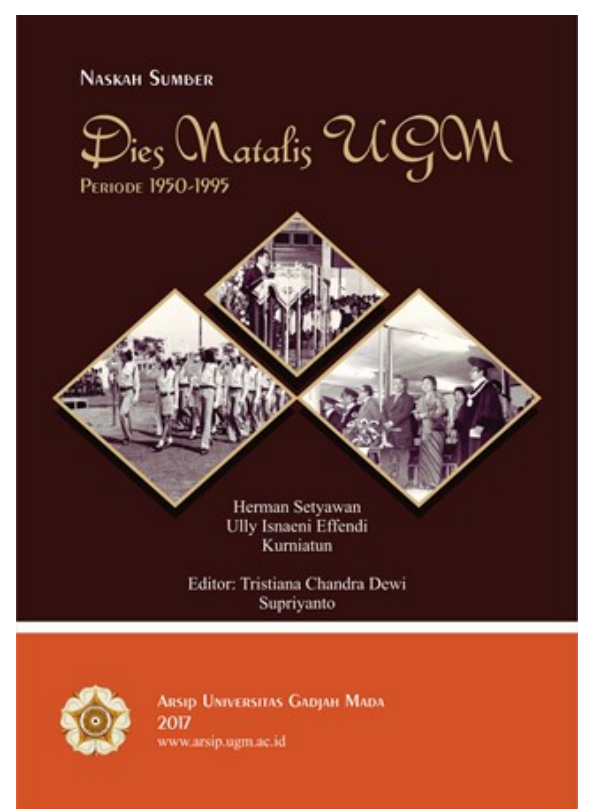

Diplomatika, Vol. 1, No. 2 Maret 2018
Naskah sumber ini secara sepesifik bercerita tentang pelaksanaan Dies Natalis UGM dari masa ke masa. Naskah sumber ini juga becerita tentang Universitas Gadjah Mada (UGM) yang didirikan pada masa perujangan. Pada tanggal 19 Desember 1948, terjadi penyerbuan oleh penjajah di berbagai daerah di Indonesia, termasuk Yogyakarta. Padahal pada waktu itu para pemerhati pendidikan di Indonesia sedang bersemangat untuk mengembangkan pendidikan di Indonesia melalui rencana pendirian perguruan tinggi. Oleh sebab itu, konsentrasi dalam bidang pendidikan terpecah dengan aksi melawan penjajah.

Dalam rangka mengingat masa perjuangan tersebut, para pejuang pendidikan di Indonesia bersepakat bahwa satu tahun setelah penyerbuan itu, tepatnya pada 19 Desember 1949, dijadikan hari lahirnya Universitas Gadjah Mada. Dalam perkembangannya, UGM memperingati hari lahirnya setiap tanggal tersebut.

Pada awal berdirinya, UGM memperingati Dies Natalisnya dengan laporan-laporan perkembangan universitas, yaitu mengenai perkembangan jumlah mahasiswa, penyediaan gedung dan sarana kuliah, alat-alat laboratorium, rumah sakit, sarana olah raga, dan perkembangan jumlah tenaga pengajar. Seiring perkembangannya, UGM memperingati kegiatan Dies Natalis dengan berbagai kegiatan olah raga, seminar akademik, pemberian penghargaan kepada insan berpresetasi, dan kegiatan-kegiatan lainnya. Dalam penyusunannya, naskah sumber ini dibagi ke dalam sembilan periode, yaitu periode 1950-1955, 1956-1960, 1961-1965, 
1966-1970, 1971-1975, 1976-1980, 1981-1985, 1986-1990, dan 19901995.

\section{KESIMPULAN}

Saat ini keberadaan Arsip Universitas sangat vital dalam rangka penyelenggaraan kearsipan di perguruan tinggi. Tanpa adanya Arsip Universitas, rasa-rasanya konsep archival administration tidak akan dapat berjalan sebagaimana mestinya. Arsip Universitas mengemban tugas yang penting, yaitu selain mengakuisisi, mengolah, dan merawat arsip, Arsip Universitas hendaknya mampu menyajikan khazanah arsipnya agar dapat berdaya guna bagi masyarakat.

Salah satu upaya yang dapat dilakukan dalam rangka publikasi khazanah kearsipan adalah dengan penerbitan naskah sumber. Hingga saat ini masih banyak tema-tema menarik yang dapat disusun menjadi naskah sumber arsip. Oleh karena itu, arsiparis hendaknya mengembangkan potensinya untuk tidak sekedar menata arsip, namun juga melayani publik melalui penerbitan naskah sumber arsip.

\section{DAFTAR PUSTAKA}

Griffin, Andrew, dkk. 2009. Glosary of Terms. London: International Records Management Trust.

Maher, W.J. 1992. The Management of College and University Archives. Metuchen, N.J.: The Scarecrow Press

Kennedy, J., \& Schauder, C. 1998. Records Management: A Guide to Corporate Record Keeping (2nd ed). South Melbourne: Longman

Lundgren, Terry (and) Lundgren, C.A. 1989. Records Management in the Compuer Age. Boston: Ken Publishing
Pearce-Moses, R. 2005. A Glosary of Archival and records Therminology. Chicago: Society of American Archivists

Peraturan Pemerintah nomor 28 tahun 2012 tentang Pelaksanaan Undangundang nomor 43 tahun 2009 tentang Kearsipan

Ricks, M \& Gow, K. 1988. Information Resources Management. A Records System Approach. 2nd edition. Cincinnati: $\quad$ South-Western Publishing

Sulistyo-Basuki. 2005. Kamus Istilah Kearsipan, Yogyakarta: Kanisius

The Society of American Archivists. 1979. Guidelines for College and University Archives. Taken from: https:// babel.hathitrust.org pada 27 Oktober 2017

Undang-undang nomor 43 tahun 2009 tentang Kearsipan

Walne, Peter. 1998. Dictionary of archival therminology. New York: KG Saur

www.arsip.ugm.ac.id diakses pada 26 Desember 2017 